\title{
Use of the Trial-Based Thought Record to Change Negative* Core Beliefs
}

\author{
Irismar Reis de Oliveira \\ Department of Neurosciences and Mental Health, Federal University of Bahia, \\ Brazil
}

\section{Introduction}

The activation of certain underlying negative core beliefs (CBs) may carry out a primary role in the manifestation of cognitive, affective and behavioral symptoms. Besides aiding the patient to identify and modify dysfunctional thoughts and emotions, helping the patient to restructure dysfunctional $\mathrm{CBs}$ is fundamental in order for therapeutic results to be consistent and long lasting (de-Oliveira \& Pereira, 2004; Wenzel, 2012). One difficulty in restructuring more superficial levels of cognition is that, frequently, the more functional alternative thoughts that are generated to challenge the dysfunctional automatic thoughts (ATs) are disqualified by thoughts (also automatic) of the type "yes, but...," derived from the activated negative CBs (de-Oliveira, 2007).

There have been several techniques developed to change dysfunctional CBs. For a review of those more commonly used, see chapter on modification of CBs in this book (Wenzel, 2012). In this chapter, I will review a novel approach to changing beliefs, namely, the Trial-Based Thought Record (TBTR; de-Oliveira, 2008; de-Oliveira, 2011d) or, in short, "The Trial."

\section{Background}

Although the Defense Attorney technique has been traditionally used in cognitive therapy (Freeman \& DeWolf, 1992; Leahy, 2003), the Trial technique (de-Oliveira, 2008) was developed as an extension of another technique, the Sentence-Reversion-Based Thought Record (SRBTR), created to deal with "yes, but..." ATs (de Oliveira, 2007). SRBTR was mainly based on the principle that, by inverting the order of certain verbal placements containing the conjunction "but," used by the patient to disqualify his/her own accomplishments, the meaning of the sentence became more favorable and tended to change his/her mood (Freeman \& DeWolf, 1992). However, some limitations, especially relative to SRBTR's implementation outside the therapist's office as homework, made its utilization difficult (de-Oliveira, 2011e).

The Trial evolved to fill in this gap, having received its name for two reasons: on the one hand it involves a simulation of a law trial, and, on the other hand, it was inspired from the work by the same name, "The Trial," by the Czech writer, Franz Kafka (1998, first published

\footnotetext{
"The word "negative" here does not intend to have a judgmental connotation; it means that the belief is unhelpful or dysfunctional, but in certain circumstances, "negative" CBs are helpful and functional.
} 
in 1925). In this book, the character, Joseph K., for unrevealed reasons, is detained by law officials, and ultimately condemned and executed without ever being allowed to know for which crime he was accused (de-Oliveira, 2011e).

Starting with the idea that Kafka was perhaps proposing self-accusation as a universal principle (de-Oliveira, 2011b), which is often implicit and out of awareness, and, therefore, does not allow for an adequate defense, this technique hypothesizes that self-accusation could be understood as a manifestation of a negative $C B$, when activated. Therefore, the rationale for developing the Trial would be to foster awareness on the patients' part of negative CBs regarding themselves (self-accusations). In this way, unlike what happens to Joseph K. in Kafka's novel, the idea is to stimulate patients to develop more positive and helpful CBs throughout the therapy.

Also, since its original format, the Trial has evolved as a technique designed to help patients to understand and deal with the overwhelming emotional burden produced by the activation of negative CBs. As experienced clinicians know, being overwhelmed by intense emotional reactions, and not knowing how to cope to their intensity, is one of the most troubling experiences for patients (Leahy et al., 2011).

The Trial incorporates in a structured format and sequence several techniques already used in cognitive therapy and other approaches: empty-chair (Carstenson, 1955), downward arrow (Beck, 1979; Burns, 1980), examining the evidence (Greenberger \& Padesky, 1995), defense attorney (Leahy, 2003; Leahy et al., 2011), thought reversal (Freeman \& DeWolf, 1992), upward arrow (de-Oliveira, 2011a; Leahy, 2003), developing a more positive schema (Leahy, 2003), and positive self-statement logs (J. S. Beck, 1995).

\section{Technique description}

Initially, the patient is asked to present an uncomfortable situation or problem (Table 1). Normally, this corresponds to the theme chosen by the patient for the session agenda. The therapist asks what goes through the patient's mind when he/she observes a strong feeling or emotion. This phase of the technique is designed to pursue the ATs linked to the current emotional state, and is recorded in column 1 . To discover which is the activated negative $C B$ (or one to be activated), responsible for these ATs and the current emotional state, the therapist uses the downward arrow technique (Burns, 1980; de-Oliveira, 2011a). For example, the therapist asks what the ATs that were just expressed mean about the patient, assuming they are true. The answer, normally expressed as "I am..." phrases, corresponds to the activated negative CB. In the example in Table 1, the patient expressed the belief "I am weak." The therapist then explains that the procedure (Trial) begins in a similar way to an investigation or inquiry with the aim of discovering the validity of the accusation (in this case, self-accusation) that corresponds to the negative $\mathrm{CB}$. The therapist then asks how much the patient finds this belief to be true and what emotions are felt. The percentages indicating the credit that the patient gives to the negative $\mathrm{CB}$ and the corresponding emotional response intensity are recorded in the lower part of column 1 , in the space where one reads "Initial." $\dagger$

tThe space where one reads "Final" will be filled in when the session is over, after the conclusion of the task called "Preparation for the appeal." Here one assesses how much the patient believes the negative 
Columns 2 and 3 of the Trial have been designed to help the patient put together information that supports (column 2) and also information that does not support (column 3) the negative $\mathrm{CB}$. Column 2 corresponds to the prosecutor's performance, where the patient is stimulated to identify all the evidence that supports the negative $C B$, taken as selfaccusation. What is normally seen is that the patient tends to produce more ATs, generally cognitive distortions, instead of evidence. I therefore suggest that the therapist not correct the patient, because later on, during the jury evaluation (column 7), the patient will be oriented to take this aspect into consideration, perceiving that the prosecutor tends to produce predominantly cognitive distortions. The information gathered and recorded in column 2 has the objective of making evident the internal arguments that the patient uses to support negative CBs.

In column 3 (defense attorney), the patient is actively stimulated to identify all the evidence that does not support the negative $\mathrm{CB}$. If the therapist perceives that the patient is bringing opinions, more than evidence, he/she can subtly suggest that the patient give fact-based examples. Although patients generally improve after the conclusion of column 3 (percentage reduction corresponding to how much they deem the negative CB to be true, and the intensity of the emotional response), some do not improve or improve very little because of a lack of credibility of the alternatives brought to challenge the dysfunctional ATs. Some patients say they believe in such alternatives only intellectually.

Column 4 (prosecutor's reply to the defense attorney's allegation) is devoted to the thoughts such as "yes, but..." that the patient uses to disqualify or minimize the evidence or rational thoughts brought by the defense in column 3, causing them to have less credit. As the example in Table 1 illustrates, by using the conjunction "but," the therapist actively stimulates the expression of other dysfunctional ATs, which maintain the negative emotional reactions and dysfunctional behaviors. The mood of the patient tends to return to the level he/she presented in column 2, during the first manifestation of the prosecutor. The therapist can then use such oscillations to show the patient how his/her mood depends on how he/she perceives the situation, positively (defense attorney's perspective) or negatively (prosecutor's perspective).

Columns 5 and 6 are the central aspects of this technique. In column 5 (the defense's rejoinder in response to the prosecutor), the patient is conducted to invert the propositions of columns 3 and 4, once again connecting them with the conjunction "but." The patient copies down each phrase from column 4 and connects it to the corresponding evidence of column 3, using this conjunction. The idea is to cause the patient to reduce the force of the dysfunctional ATs. The result is the change of perspective of the situation to a more positive and realistic one. At this time, the patient is stimulated to read each one of the inverted sentences in column 5 and record in column 6 the new meaning, now positive, brought about by this strategy used by the defense attorney. The use of the upward arrow technique starts here, the therapist asking the meaning of each inverted sentence, and stimulating the patient to go further by means of the adverb "therefore". For instance, in the dialogue

core belief (e.g., "I'm weak"), after its deactivation and the activation of the positive core belief (e.g., "I'm strong"). 
between the therapist and Maria (playing the role of the defense attorney), shown in this chapter, after inverting the sentence, Maria came with "She (Maria) was away from her job for a long time, but she has 3 college degrees." Then, she added: "It seems she's not as weak as she thought. Therefore, she's not weak."

Column 7 contains the analytical part of the Trial, presented under the form of a jury deliberation. Taking the juror's perspective, the patient answers a series of questions involving the performance of the prosecutor and the defense attorney. Although many questions may be answered by the patient as a juror (e.g., Who was most consistent? Who was most convincing? Who used more fact-based information? Was there intent on the part of the accused?), the main question to be considered is: Who had the least cognitive distortions? Here, in the majority of cases, the patients acquit themselves of the accusation, represented by the negative $C B$, after they identify the cognitive distortions made by the prosecutor and notice that the defense attorney made no cognitive distortions.

The credit the patient attributes to the negative $\mathrm{CB}$ and the intensity of the corresponding emotion are evaluated at the end of each character's performance, being recorded in the lower part of all the columns (with the exception of column 5). Such percentages demonstrate the oscillation of the patient's emotions when his/her attention is focused on negative perceptions (prosecutor) or positive ones (defense attorney).

Finally, this thought record is used to activate (or even develop) new positive CBs through the above mentioned upward arrow technique (de-Oliveira, 2007; de-Oliveira, 2011a), in counterposition to the downward arrow (Burns, 1980) used in column 1. For this, the therapist asks: "Supposing the defense attorney is right, what does this say about you?" In the example of Table 1, the patient brings up the new positive CB "I am strong."

Table 2 is the homework record that the patient will be asked to fill in, being encouraged to gather on a daily basis, during the week, the elements that support the positive $\mathrm{CB}$. The homework is assigned as a preparation for the appeal requested by the prosecutor when the patient acquits him/herself of the accusation, or, more rarely, requested by the defense, when the patient does not consider him/herself innocent at the end of the Trial. Also, the patient indicates daily how much he or she finds the new $\mathrm{CB}$ to be true.

Table 3 was adapted to fit in two or more positive CBs, when several trials and appeals have been carried out. Notice that the time taken by the patient to do the homework will be the same, regardless of how many positive $\mathrm{CBs}$ he/she might be nurturing in the diary. A fact, a piece of evidence or element that supports a new positive belief may support others, and in this way the patients always keep watch over the activity of the previously restructured negative CBs that, frequently, become active again if they are outside the attention span. Therefore, this form allows patients to strengthen several new positive CBs simultaneously.

The fundamental aspect at this stage is that the patient take time outside the session to pay attention to the facts and events that support the positive $\mathrm{CBs}$, and this implies that the defense attorney be chosen as an ally, regardless of whether or not the patient has been absolved at the end of each Trial. 


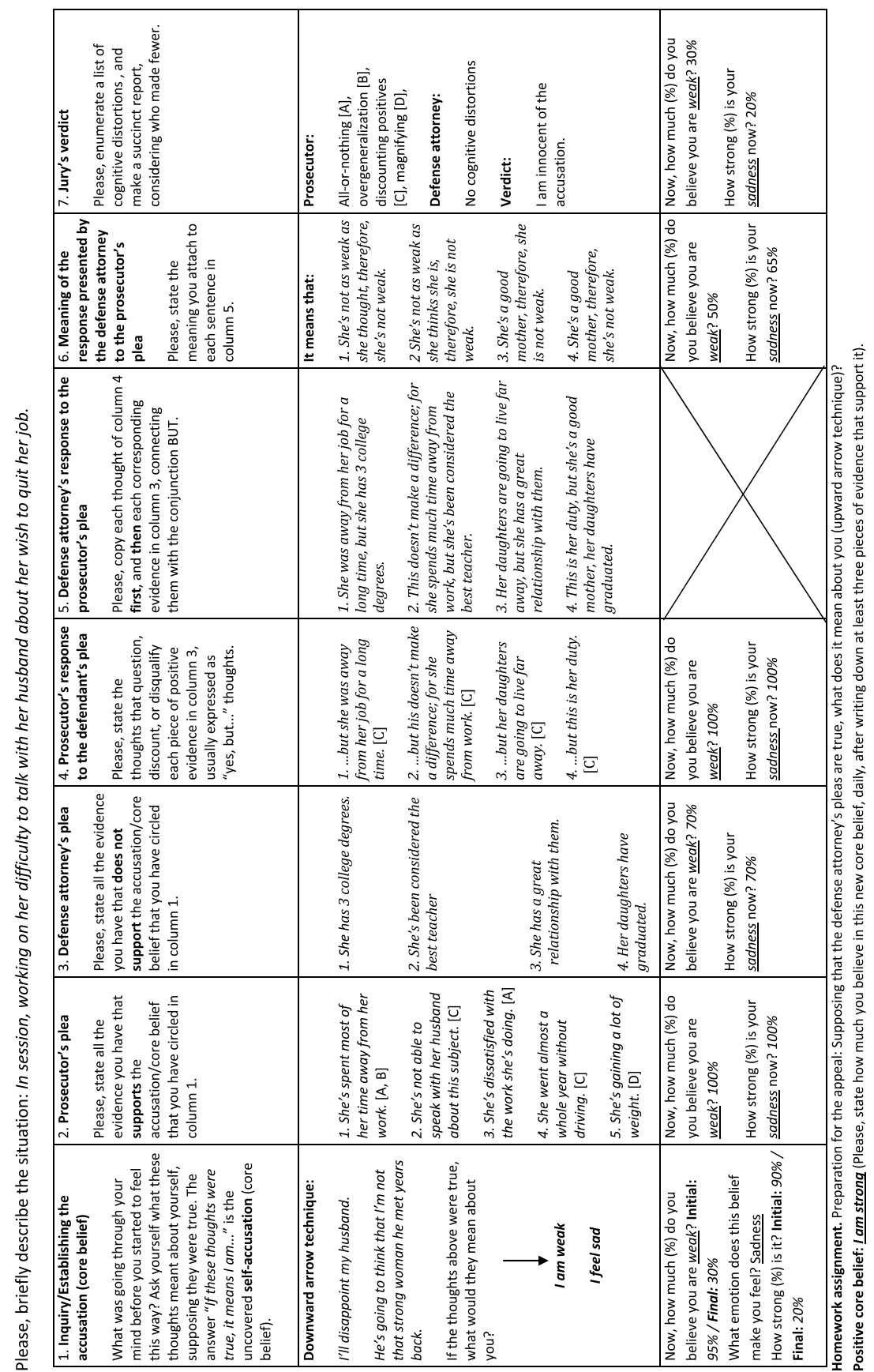

Table 1. Illustration of the Trial-Based Thought Record (Copyright: Irismar Reis de Oliveira; http://trial-basedcognitivetherapy.com). 
Positive core belief: I am strong.

Please, write down here, daily, at least one piece of evidence supporting the new core belief. Also, please, write how much (\%) you believe the new core belief in the space between parentheses

\begin{tabular}{|c|c|c|c|c|c|c|}
\hline $\begin{array}{l}\text { Date: }(50 \%) \\
\text { 1. I got up early and went to work, } \\
\text { despite wanting to stay in bed. } \\
\text { 2. I came to therapy even when I } \\
\text { didn't want to. } \\
\text { 3. }\end{array}$ & $\begin{array}{l}\text { Date: } \\
1 . \\
2 . \\
3 .\end{array}$ & ( \%) & $\begin{array}{l}\text { Date: } \\
1 . \\
2 . \\
3 .\end{array}$ & ( \%) & $\begin{array}{l}\text { Date: } \\
1 . \\
2 . \\
3 .\end{array}$ & ( \%) \\
\hline 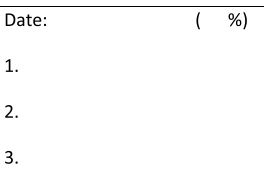 & $\begin{array}{l}\text { Date: } \\
1 . \\
2 . \\
3 .\end{array}$ & ( \%) & $\begin{array}{l}\text { Date: } \\
1 . \\
2 . \\
3 .\end{array}$ & ( \%) & $\begin{array}{l}\text { Date: } \\
1 . \\
2 . \\
3 .\end{array}$ & ( \%) \\
\hline 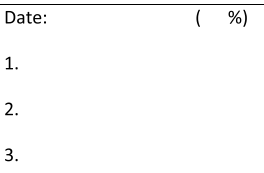 & $\begin{array}{l}\text { Date: } \\
1 . \\
2 . \\
3 .\end{array}$ & ( \%) & $\begin{array}{l}\text { Date: } \\
1 . \\
2 . \\
3 .\end{array}$ & ( \%) & $\begin{array}{l}\text { Date: } \\
1 . \\
2 . \\
3 .\end{array}$ & ( $\%)$ \\
\hline 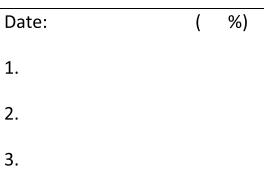 & $\begin{array}{l}\text { Date: } \\
1 . \\
2 . \\
3 .\end{array}$ & ( \%) & $\begin{array}{l}\text { Date: } \\
1 . \\
2 . \\
3 .\end{array}$ & ( \%) & $\begin{array}{l}\text { Date: } \\
1 . \\
2 . \\
3 .\end{array}$ & ( \%) \\
\hline
\end{tabular}

Table 2. Appeal preparation - one-belief form (Copyright: Irismar Reis de Oliveira; http://trial-basedcogitivetherapy.com).

\section{Research carried out}

In the first article describing the Trial (de-Oliveira, 2008), a modified version of the sevencolumn Dysfunctional Thought Record (Greenberger \& Padesky, 1995) was proposed to change negative CBs by way of combining a strategy involving sentence reversion (Freeman \& DeWolf, 1992) and the analogy to a Law trial (Leahy, 2003). The patients $(n=30)$ took part in a jury simulation and showed changes in their attachment to negative CBs as well as in the intensity of corresponding emotions after each step during a session (investigation, prosecutor's allegation, defense attorney's allegation, prosecutor's reply, defense's rejoinder and jury's verdict). The results of this work showed significant mean reductions between the percentage figures after the investigation (taken as baseline), after the defense allegation $(p<0.001)$ and after the jury verdict, from the beliefs $(p<0.001)$ as well as from the intensity of emotions $(p<0.001)$. Significant differences were also observed between the first and second defense allegations $(p=0.009)$ and between the second defense allegation and the jury verdict with respect to the CBs $(p=0.005)$ and to the emotions $(p=0.02)$. The conclusion was that the Trial could, at least temporarily, help the patients in a constructive way to reduce the attachment to negative core beliefs and the corresponding emotions (de-Oliveira, 2008). 
Please, write down here, daily, at least one piece of evidence supporting each new core belief. Also, write how much (\%) you believe the new core belief in the space between parentheses.

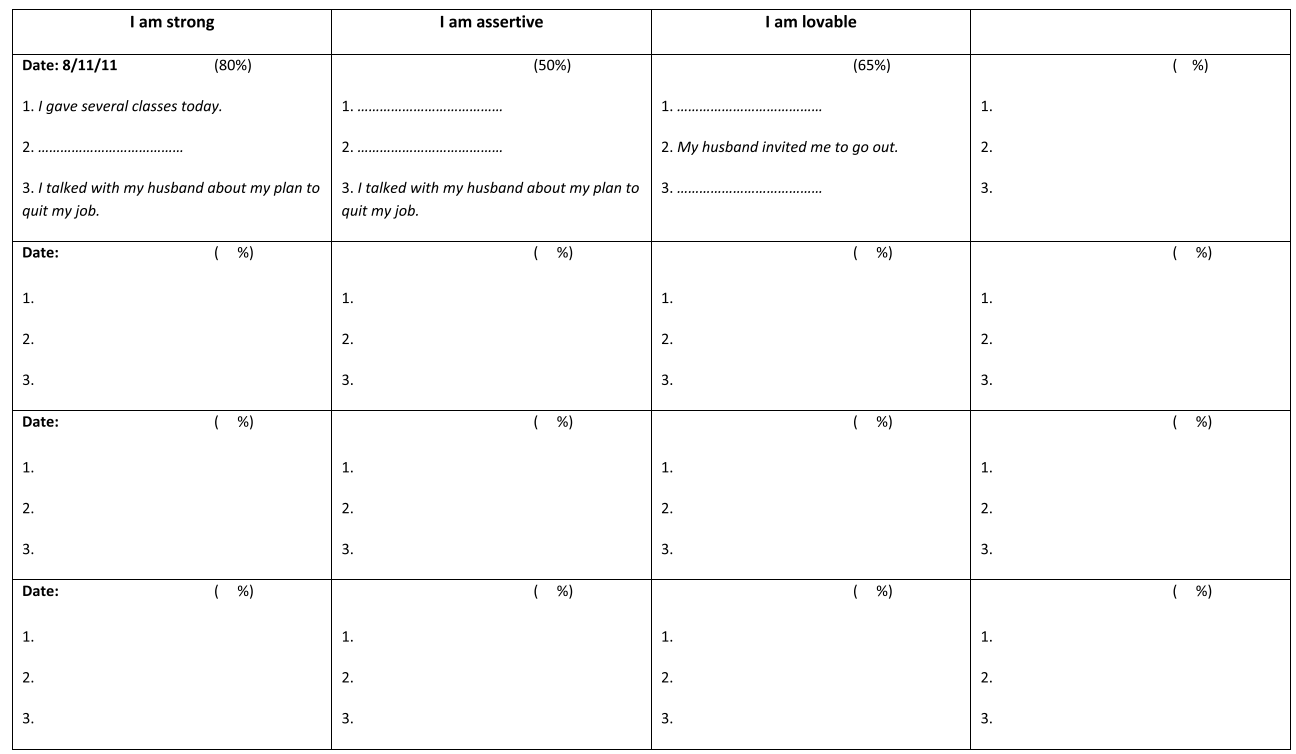

Table 3. Appeal preparation (two or more beliefs form). (Copyright: Irismar Reis de Oliveira; http:/ / trial-basedcognitivetherapy.com).

A clinical trial was recently completed (de-Oliveira et al., 2011) in which the Trial was studied in 36 patients with social phobia, randomly assigned to the experimental group treated with the Trial $(n=17)$ and to the contrast group $(n=19)$, this latter group treated with a conventional model of cognitive therapy that included the seven-column Dysfunctional Thought Record (DTR; Greenberger \& Padesky, 1995), associated with the Positive Data Log (PDL; J.S. Beck, 1995). Both groups received psycho-education regarding the cognitive model and types of cognitive distortions, and discussed with the therapist individualized case conceptualization structured according to Judith Beck's conceptualization diagram (1995). The objective of both treatments was to restructure the CBs in order to reduce the symptoms of social phobia. Exposure was not actively stimulated in either of the groups. When a mixed ANOVA was carried out, significant reductions were observed $(\mathrm{P}<0.001)$ in both approaches on scores in the Liebowitz Social Anxiety Scale (LSAS; Liebowitz, 1987), the Fear of Negative Evaluation Scale (FNE; Watson \& Friend, 1969), and in the Beck Anxiety Inventory (BAI; Beck et al., 1988). Nevertheless, the one-way ANCOVA, taking the baseline data as co-variables, showed that the Trial was significantly more effective than the contrast group in reducing the FNE $(\mathrm{P}=0.01)$, and social avoidance and distress $(\mathrm{P}=0.03)$. The results described above justify new studies to assess the efficacy of the Trial not only in social phobia, but also in other psychiatric diagnoses. 


\section{Trial demonstration session ${ }^{\ddagger}$}

Therapist: Good morning, Maria.

Patient: Good morning, Dr. Oliveira.

T: How are you?

P: All right.

T: We have been working on an issue that has worried you a lot. So then, last week we saw this question of your decision to stop your current activity working as a teacher.

P: That's right.

T: But this is something which is giving you much doubt; during all this psychotherapeutic process that we have gone through here, this seems to have really been your great concern, and this has been a recurrent theme, hasn't it? Could you sum up our last session and what impact it had on you?

P: Yes. As during the last session we worked on the fact that I made up my mind (and this has been very difficult for me), I thought that it was important that last week we went over the advantages and the disadvantages. But this is something I had already been doing for some time.

T: We did it a little differently last time, because you had been using, for some time now, this technique of the advantages and disadvantages, but we were able to go a little further and focus on the role of reason and emotion; this internal conflict you have (one time it seems that your head tells you something, then another time it's your feelings talking). Has this changed any?

P: No, not really.

T: And you could see that actually, at that moment, the decision was not made.

P: That's right, but, although I hadn't made up my mind, I felt between then and now a little more relieved, because the impression I had before was of being paralyzed, and I wasn't doing anything to try to resolve the situation. Now, even though I haven't made a decision yet, this is the time that (as we say) I will begin to work through some situations, doing small tasks, to get better information on what is going on around me, in order to decide some time later.

T: Of course. It's important to say that the technique is called consensual role-play§ and that it really seems to have helped you to feel more at ease, because you didn't have any obligation to make a decision, but it would be important because of what you would be learning with the situation.

P: Right.

‡This is a simulated session of a patient with Maria Eduarda Guedes, PsyD. The filling in of the corresponding forms, "Trial" and "Preparation for the appeal," are in Tables 1 and 2, respectively. I suggest that the reading of this demonstration be carried out at the same time as the tables.

$\S$ This technique is described in Chapter 1. 
Step 1. Inquiry

T: Tell me something, Maria: it seems to me that during this week you are still worried about this...

P: I am.

T: What has been going through your mind regarding this question of making a decision (although you told me that it is a little less difficult than before)?

P: The main issue that comes to mind is regarding my husband. I think he is the main point, because I always get the impression that I won't do what he expects me to do.

T: Exactly. And this really has been the focus of your greatest concern?

P: Yes, because this prevents me from speaking with him. A large part of my decision to not leave (of course it also has to do with the dream I've always had of being a teacher) is also because of my concern over not disappointing my husband.

T: Ok. And at these times that you are thinking of this, that is, in how to put this to your husband, in how to talk to him about this, or even the issue of maybe disappointing him, what are the thoughts and ideas that have gone through your mind?

P: First, that I will disappoint him.

T: “I'll disappoint him." Has anything else gone through your mind about this?

P: He's going to think that I'm not that strong woman he met years back.

T: So he'll think that you aren't that strong woman he once knew.

P: Right.

T: And, if it's true (only when we start from the principle that this thought may be true), what does this mean to you?

P: That in fact I am not strong anymore... so, that I am weak.

T: Ok. Is this an idea that goes through your mind once in a while?

P: Yes! Every time I think about the idea of leaving my position as a teacher, I get this idea that I'm being weak, that I could keep on trying...

T: That's interesting, Maria, because we have talked a lot during therapy, and since the beginning (when I showed you this psychotherapy model), you could see this conceptualization diagram that seems to have helped. And what is interesting is that many of these ATs that I explained to you and that are at the first level, are often the result of the idea you have of yourself, of how you see yourself as a person, which we call...

P: Core belief.

T: Core belief, you remember very well. If we were to put this down as an activated core belief, and wrote down here "I'm weak," would this make sense to you? Can you see this as this arrow going up here, nurturing these thoughts? [Therapist points to the arrow going from the core belief box to the ATs box (Fig. 1.)] 


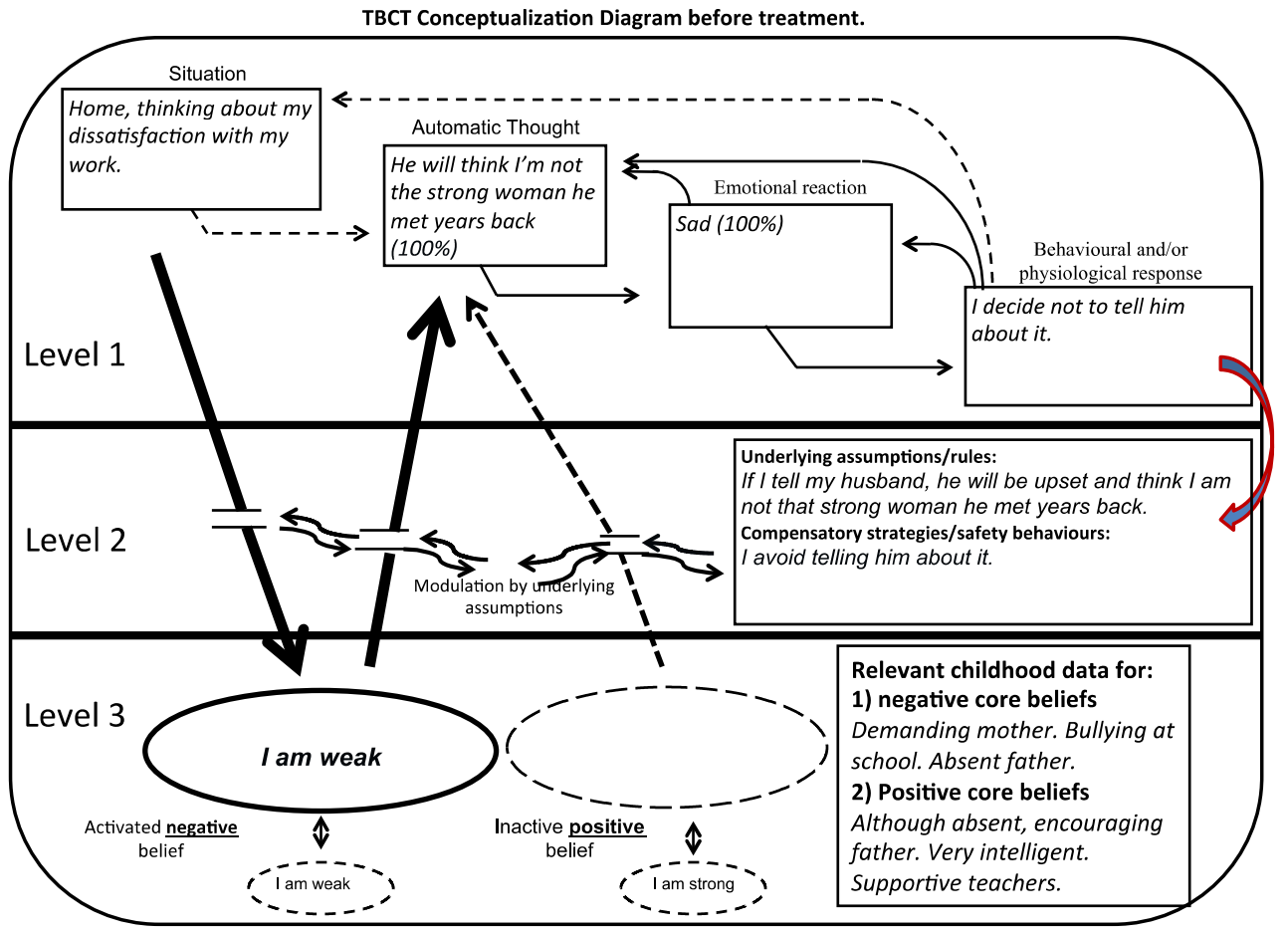

Fig. 1. Maria TBCT conceptualization diagram (Phase 1), showing the negative core belief activated more frequently before treatment.

\section{P: That makes sense.}

T: Would it be worthwhile for us to work on this idea a bit, this concept that you are presenting here, which seems to return every now and then?

P: Yes.

T: What I want to propose to you today is that we work with this by using something that hasn't been done yet in our sessions; it's a technique called "The Trial." In this technique, the central idea that people are burdened about themselves (in your case, "I'm weak") is like a type of self-accusation, it's how you see yourself, isn't that right? I'm going to write down on this form exactly this: "I'm weak;" and you saw that we had several thoughts that were written here, related, even, to the question of your husband, and the phase of this technique corresponds to what we call the investigation; and in the investigation (assuming these thoughts are true) you yourself came to this conclusion: "I'm weak." How much do you believe this, Maria ("I'm weak"), now?

P: Today, now, $100 \%$.

T: $100 \%$. By believing this $100 \%$ ("I'm weak"), what do you feel? What is the emotion that corresponds to this? 
P: I feel sad. I've felt like this for some months...

T: "Sadness." Ok. If you had to evaluate the amount of this sadness, what would it be now (from 0 to 100)?

P: When I think that I am weak, it is $100 \%$.

Step 2. Prosecutor's plea

T: $100 \%$ also, right? Now I would like us to follow this same line of thought (as if you were in a tribunal, a courthouse) and that, taking this as a self-accusation, I want you to prove to me that this is true, that you are weak, all right? One thing I want to ask you to do (and it's something you've already started doing in the consensual role-play technique we used last session) is to live out these internal characters. So, for example: we have several empty chairs here and in that chair over there in front (where I'd like you to sit now), you will be yourself, Maria. Can you do this? You are being placed as a defendant, and the charge is "I'm weak." When we did the investigation just a while ago, you said that you believe this very much. Do you, Maria, seated there, maintain this belief at 100\% (how much do you believe it)?

P: Yes.

T: Ok. And is the sadness still high?

P: It's still at $100 \%$.

T: Why don't you sit down in this chair? And now you will represent one of your internal characters, the one that accuses you of being weak. Can you sit down over here?

P: I think I'm good at this!

T: You're good at this, great! Ok then, you will make the charge against Maria, who is seated in that chair, and you will prove, bring the arguments that you have as a prosecutor to accuse her of being weak.

P: She's spent most of her time on leave of absence or away from her work.

T: Ok. "She's spent most of her time away from her work."

P: Right. She's not able to speak with her husband about this subject.

T: "She's not able to speak with her husband about this subject."

P: She's dissatisfied with the work she's doing.

T: Ok. So "she's dissatisfied with the work she's doing."

P: She has had more than one crisis during some classes. She went almost a whole year without driving.

T: Ok. "She went almost a whole year without driving."

P: And now, Dr. Oliveira, she's gaining a lot of weight and she can't lose it.

T: Ok. "She's gaining a lot of weight." I'd like you to go back to that chair. See what you've just heard from this character, the prosecutor, really trying to prove that you are weak, with 
the following arguments: You've spent most of your time away from your work; you can't speak with your husband about this subject; you are not satisfied with the work you are doing; you've already had more than one crisis during classes; and you went almost a year without driving, besides gaining a lot of weight. When you hear these arguments voiced by this character that just expressed herself, how much do you believe this ("I'm weak")?

P: $100 \%$

T: $100 \%$. And the sadness?

P: $100 \%$. Can I make it $110 \%$ ?

T: Ok. Actually, we can have an idea that, if it is at $100 \%$ now (and it was weaker before), maybe it wasn't at $100 \%$ before. Would you like to re-evaluate...?

P: I don't know, 95\% before.

T: $95 \%$ before, and the sadness was as high as it is now?

P: It's higher now.

T: So, how much was it before, if now you consider it as being $100 \%$ ?

P: $90 \%$ before.

Step 3. Defense attorney's plea

T: Ok, 90\% before. Maria, once in a while, don't you give a chance to the other side (to the character that is the defense attorney) to express itself, to be manifested? I'd like you to do that now. We are in a tribunal, why don't you sit in this chair now, and answer the accusations made by the prosecutor? That is, Maria is in that chair, you have put yourself here as her defense...

P: I'm supposed to defend, right? I'm not very good at this.

T: What is interesting is that maybe your character that would be from the defense has not had much chance to express itself, and to begin with, maybe one of the great difficulties is the concept of a defense attorney. Is the defense attorney obliged to believe in the innocence of the accused?

P: No.

T: That is, everyone deserves a defense. If you had to speak about her, Maria, and defend her as your client, what arguments would you bring forth? All a defense attorney has to do is do a good job, right?

P: I'm not sure, Dr. Oliveira, if the fact that I've gotten 3 university degrees counts....

T: Ok. Is it a fact? Is it something that really speaks in favor of Maria?

P: Yes, it does.

T: That is, "she's gotten 3 degrees."

P: On the other hand, this could be considered a failure.

$\mathrm{T}$ : The interesting this is: who is talking now? 
P: The prosecutor.

$\mathrm{T}$ : Is this the time for the prosecutor to speak?

P: No.

T: What is your role in this case, seated in that chair?

P: The defense.

T: Exactly, and from the defense's point of view, what will you say regarding your client? You consider this as what?

P: A fact.

T: A fact that really defends her.

P: Besides the 3 degrees, she's been considered a good teacher.

T: So, "she's been considered a good teacher..."

P: ...one of the best. Last month, we had a 'teacher week' in her city, and normally the teacher with the best performance is chosen. She was the chosen one.

T: OK. Can you bring more elements in defense of Maria?

P: She has a great relationship with her daughters, but...

T: "But..."

P: The prosecutor is speaking, and it's not her turn.

T: So, let's call attention to the prosecutor so that she will really be silent at this time, because her place is here [the therapist points to the other chair] and, when the time comes for her to speak, she will have all the freedom to do so, but, right now, she remains silent, right? So, you, as the defense attorney, would say what?

P: She has a great relationship with her daughters.

T: Any other element?

P: I think that the fact that her daughters, today, have both graduated (one is a lawyer and the other an architect) indicates that she's a good mother.

T: "She's a good mother." So, while writing this, it would be interesting to put down exactly what shows that she is a good mother, so we can put it in parentheses as a reminder.

P: The fact, right, doctor?

$\mathrm{T}$ : The more facts, the better.

P: Her daughters have graduated from college.

T: "Her daughters have graduated." Maria, now, I'd like you to return to that chair again, and listen to what your defense attorney has just stated. You have 3 different college degrees; You've been considered the best teacher; You have a great relationship with your daughters; You're a good mother (what proves this is that your daughters have even graduated). While listening to your defense attorney, how much do you believe this ("I' $\mathrm{m}$ weak")? 
P: I believe it a little less... around 70\%.

T: What happens to the sadness, Maria?

P: It also goes down... to $70 \%$.

Step 4. Prosecutor's second plea

T: 70\%. Now, I'd like you to return to this chair over here. This is the time the prosecutor can speak again. Would you come over here? Normally, at this time in this type of activity, the prosecutor has already used the arguments she had, and, generally speaking, what she will do is to "undo" what was said by the defense. Usually the prosecutor uses the conjunction "but," and this is what I'm going to give you the chance to do. That is, the defense attorney said: "She has 3 different degrees," but...(what does the prosecutor say?).

P: ...but she was away from work for a long time.

T: Ok. "She was away from work for a long time."

P. ...which makes her feel dissatisfied.

T: "She's been considered the best teacher," but...

P: But this doesn't make any difference, since she's away from her job so much!

T: “This doesn't make any difference, since she's away from her job so much." Ok. "She has a great relationship with her daughters," but...

P: The one she's closest to got married and lives in São Paulo.

T: And how would you sum that up?

P: They are becoming more distant.

T: “They are becoming more distant." Distant in the sense of living farther away, isn't that right?

P: Yes.

T: This is for us to have an idea of what "more distant" means...

P: ... and the other one is also getting married.

T: "They're going to live far away." "She's a good mother, her daughters have graduated," but...

P: This is her duty; make sure her kids get a college education.

T: "This is her duty; making sure her kids get a college education." Ok? Why don't you return to that chair, as Maria? And what you've just heard from the prosecutor, who was seated here, was: You were away for a long time (regarding the question of the college courses you were taking); This doesn't make any difference, since you're on leave a lot and don't work as a teacher; They are living far away (here, you are referring to your daughters); This is your duty, making sure they get a college education. While listening to your prosecutor, how much do you believe this ("I'm weak")?

P: This technique isn't helping me, because I've gone back to believing 100\%: I'm a failure. 
T: $100 \%$, "I'm a failure." So it goes up. And what about the sadness, what happens?

P: It goes up as well.

T: As well, $100 \%$. This is very important, what you've just said... - and I apologize for perhaps making you feel uncomfortable. Might this be what happens outside this office? Which voice do you listen to more outside, the prosecutor's or the defense attorney's?

P: I almost don't hear the voice of the defense attorney.

$\mathrm{T}$ : And the prosecutor is always speaking?

P: Yes.

T: Wasn't this what she just did? She just spoke. And what can you learn right after hearing what was said by the prosecutor (something that appears to be very frequent in your life)?

P: That I'm always blaming myself...I'm always bringing accusations against myself.

T: Doesn't it seem that way?

P: Yes.

Step 5. Defense attorney's second plea

T: Ok. So what if you did the same thing now, here in this chair (where you'll be seated as your defense attorney)... Can you do this now?

P: Yes, I can.

$\mathrm{T}$ : What is interesting is that you can use the same strategy used by the prosecutor; in this case you'll also use the conjunction "but." In the same way that the prosecutor didn't seem to have many more arguments than those already used, nor does the defense attorney, but the good news is that it isn't necessary. What I'd like to ask you to do now, Maria, is the following: why don't you copy down exactly what was said by the prosecutor?

P: "She was away from her job for a long time."

T: And I'd like you to add the conjunction "but" right after that.

P: "But..."

T: I'd like you to copy down exactly what was said by the defense.

P: “...but she has 3 different college degrees."

T: Can you read this sentence to me again?

P: "She was away from her job for a long time, but she has 3 college degrees."

T: What does this mean to you, as Maria's defense attorney?

P: This means that it seems she's not as weak as she thinks she is.

T: Why don't you also place a number to correspond exactly to what you just told me?

P: “This means that..."

T: “...it seems that she's not as weak..." 
P: "It seems she's not as weak as she thought."

T: I'd like you to add the word "therefore" here. I'd like you to finish the sentence.

P: Therefore, she's not weak.

T: Why don't you write exactly this? It would be enough for you to just repeat this same strategy.

P: “This doesn't make a difference; for she spends much time away from work, but she's been considered the best teacher."

T: What does this mean about Maria?

P: Again, this means that she's not as weak as she thinks she is.

T: Why don't you write down exactly this?

P: "She's not as weak as she thinks she is."

T: Therefore...?

P: Therefore... she is not weak.

T: Can you do the same thing with the other one?

P: "Her daughters are going to live far away, but she has a great relationship with them."

T: What does this mean to you?

P: It means that she's a good mother.

T: Why don't you write down there exactly this?

P: Therefore... she is not weak.

T: Can you do that with the last one?

P: This is her duty; making sure that her kids get a college education, but she's a good mother, her daughters have graduated.

T: What does this mean to you?

P: It means, again, that she's a good mother.

T: Why don't you write that down there?

P: Therefore... she's not weak.

T: Maria, I'd like you to once more take your seat and say, with these facts before you or from what was just said by your defense attorney (It seems that you are not as weak as you thought, therefore you're not weak; This means that you're not as weak as you thought, therefore - once again - you're not weak; You're a good mother, therefore you're not weak; You're a good mother - again - therefore, you're not weak), facing all this, how much do you believe ("I'm weak")?

P: $50 \%$.

T: $50 \%$. What happens to the sadness? 
P: I'm a little more relieved... 65\%.

Step 6. Jury's verdict

T: $65 \%$. Maria, here's the thing: in this phase of a tribunal, the prosecutor had a chance to speak, so did the defense; there was the rebuttal of the prosecutor; there was the rejoinder from the defense; what is the next step in a judicial process such as this one?

P: The jury's decision?

T: Exactly, the jury meets alone. What I'd like you to do now, Maria, is exactly that: could you sit in that chair and take the place of juror number 1? So, imagine yourself now gathered in a room with several people; you have all the time in the world, although here, actually, we only have a few minutes left for this. But I'd like you to picture yourself gathered with this body of jurors and that you'd leave here with a unanimous result. And I'd like to ask you as a juror, what is the role of a jury member?

P: Evaluate what was said by the prosecutor as well as by the defense attorney; weigh the facts and reach a verdict.

T: Ok. And normally these jurors would answer some questions such as: which of the two was more consistent, more convincing, was based more on facts and distorted the facts the least? And here we are speaking of cognitive therapy, so, of the cognitive distortions. Who was more concerned with the dignity of the accused? Were there any mitigating circumstances? Was there any intent? So, these are the questions that are asked when the jurors meet. I'd like you to see, in this case, how a juror really should act, therefore, with objectivity and ethics. And it would be very interesting (if you've already seen the movie "12 Angry Men") for you to picture yourself in the room with the jurors.

P: So I have to...

T: ...observe what was said by the prosecutor and the defense attorney, and the prosecutor's rebuttal, then the defense attorney again, and try to answer these questions.

P: So here the prosecutor said that she's spent most of her time away from work... I think that here - although it is true -, in the last year she returned to her job and has worked more than she's gone on leave.

$\mathrm{T}$ : Therefore, is there some level of cognitive distortion in that?

P: Yes.

T: From what you've already learned through our work, could you name these distortions?

P: I think overgeneralization, she's overgeneralizing here... But I can see that, besides this one, the prosecutor used very concrete facts. "She can't speak with her husband." This is a fact... about this subject.

T: Even if it's a fact, would you consider that, as a juror, there is some cognitive distortion?

P: It's not all the time that she can't talk with him; she really does talk with him about many things, but regarding this subject she hasn't been able to. 
T: So you could see that, according to the prosecutor, the fact of not being able to speak with him indicates that she is weak. What conclusion do you reach from this?

P: That the prosecutor was heavy handed.

T: Ok.

P: "She's not satisfied with the work she does." This is a fact. People can say this or that regarding her classes, but long ago she got pleasure from what she did; today she doesn't, so this is a fact.

T: Ok. If you take into consideration that all those questions (mitigating circumstances, intent, a series of other things on which a juror really bases himself on), is this enough to accuse her of being weak or would you say that there is a problem with that?

P: No, it isn't enough. It's a fact, it's true, but in and of itself it doesn't make her a weak person. "She's had several crises in classes." This is real and it makes her a weak person. But, with regard to the defense attorney, the elements stated were really very damaging, even convincing. So, "she has 3 degrees"... Although, Dr. Oliveira, every time I think of this I get the impression that I was never able to stick with any of the courses...

T: Ok. Which character are you incorporating right now?

P: The prosecutor.

T: But you are there as a juror, even to hear the prosecutor, right?

P: So I guess the defense attorney did a good job here.

T: Is there any distortion, something not based on facts?

P: No, it's true. "She's been considered a good teacher," that is real. "She has a great relationship with her daughters," this is very true. "She's a good mother"... I don't think that the fact that her two daughters graduated from college is an indication of her being a good mother.

T: And are you speaking now as the prosecutor, the defense or the juror?

P: I think as the juror; I'm denying what the defense said.

T: Ok. The interesting thing is that, strictly speaking, you are taking only one aspect into account, right? And a juror will analyze many aspects. And when you analyze all this as a juror, even upon seeing the other points stated by the prosecutor and the defense attorney...?

P: The elements the defense attorney brings me have more weight.

T: OK. Would you say that you are close to reaching a position of unanimity, considering that context we cited, to give the verdict?

P: Yes... the verdict is that she's innocent.

T: Why don't you write that down exactly?

$\mathrm{P}:$....since the proof the defense attorney brings is more convincing. I think that's it. 
T: So why don't you return to that chair, Maria? You heard the juror that brought this result, this verdict that considers you innocent of this accusation brought by the prosecutor. At this time, how much do you believe this (“I'm weak")?

P: It's still there, but the way I believe it is weaker... so I guess it's around $30 \%$.

T: $30 \%$. What is happening to the sadness now, how big is it?

P: It's a lot more reduced, at $20 \%$.

Step 7. Preparation for the appeal

T: $20 \%$. What we could do now, Maria, is precisely a question that is extremely important. You've just heard all these internal characters; would you say that the prosecutor, upon receiving the result that she lost at this time, is going to be satisfied, or will something make her speak out?

P: Always, she'll always want to speak out.

T: What way will she speak out?

P: Raising more issues.

T: So, it seems to me that she is asking for an appeal... and we will give her this appeal. That is, as many times as it is necessary, we'll return to this tribunal. If the defense had lost, we'd also give it the possibility of an appeal. Ok, but there is a very important choice for you to make now: who do you choose as your ally? The prosecutor who was seated in that chair, or the defense attorney?

P: The defense attorney.

T: If the defense attorney is right in having you acquitted now, if the juror is right in giving you this verdict, what does this mean about you, Maria?

P: If the defense attorney is really right? This proves that I'm not weak.

T: Therefore you are...

P: I still wouldn't say that I am strong...

T: Ok. Whose voice would you say - even if you don't yet affirm it - that you are trying to listen to?

P: The defense attorney's.

T: The defense? Saying that you are still not that strong?

P: No, no, the prosecutor's!

T: The prosecutor's. And who are you choosing as your ally?

P: The defense attorney.

T: This attorney who was seated here, with all those arguments, did she at any time doubt that you were innocent? No. Therefore, what would the defense attorney say, if she were in your place? 
P: She'd say "I am strong."

T: Why don't we give credit to the defense attorney, who was so absent and had so little opportunity to speak? And if we wrote down on this other document... and from now on, I'd like us to sit over here at this table... here's the thing: I'd like you to prepare yourself for the appeal requested by the prosecutor. And you are placing here the very document of the defense, which I'd like to present to you. What does a good defense attorney do between hearings, when he is working on a case?

P: He continues looking for evidence and elements in favor of his client.

T: And when he doesn't find any, what does he do?

P: He continues searching.

T: He continues searching, therefore, he doesn't stay still. This means we are talking about an ethical attorney; seek does not mean forge, it means going after facts. And I have something in mind on speaking of this: what are the facts that represent who we are? Are they the heroic ones, or the small facts of our routine?

P: Although I think it's the heroic facts, rationally speaking, it's the day-to-day facts.

T: It's these facts that say who we are.

P: Yes.

T: These facts will say whether we are weak or strong. And what conclusion did your defense attorney reach?

P: That I am strong.

T: So, would you have any objection if we placed here, at least temporarily, "I am strong"?

P: Temporarily, no.

T: Even if it is temporary, would there be any possibility of you, on a daily basis and along with your defense attorney, looking for up to 3 facts that would indicate that you are strong, to help your defense attorney's performance?

P: It does take some time to do this...

T: What if we tested out this idea now? For example, if you had to think about today, would you be able to (from the time you got up) bring some elements that demonstrate this, since you came to the conclusion that we don't really need a heroic fact for such?

P: So little has happened today that I can't take anything into consideration...

T: Ok, so describe to me a little of your day so far.

P: My alarm clock went off at 7 this morning and I was still very sleepy.

T: Ok, what happened following that?

P: I got up.

T: What did you feel like doing right then? 
P: Staying in bed.

T: And when you got up despite wanting to stay in bed, what did this mean?

P: That I got up... that I wasn't weak at this time.

T: Ok. So, even with this small doubt, could you write it here as an item that describes this?

P: Oh, Dr. Oliveira, it's my obligation, I have to get up and go to work!

T: Ok. And what character is speaking right now?

P: The prosecutor.

T: And the question I ask you is this: whose is this document?

P: The defense attorney's.

T: And therefore, you are allowing the prosecutor to use a document that isn't hers? Ok, it doesn't matter that the prosecutor says this. This document belongs to the defense attorney and it appears as though you decided to work with her. So, if you are working with the defense - even if you, Maria, have doubts, or don't have much desire to do so because you still don't trust your defense attorney very much - would it be possible to give her a vote of confidence by writing this down?

P: "I got up early and went to work."

T: It seems that you stated this another way, "despite..."

P: “...despite wanting to stay in bed."

T: Ok. Does this give it a somewhat different connotation? Could you state another fact? If you find it difficult, continue talking about your morning... what happened next?

P: I didn't want to come here today.

T: Ok. Was it difficult to come here today?

P: Yes, because I was already late leaving a class, I arrived here late, I thought there wouldn't be enough time, and I didn't feel like coming anyway...

T: And what did you do?

P: I came.

T: And what does this mean?

P: That... I was strong...?

T: Isn't this a small element nurturing this here ("I am strong")? And in fact, you don't need any heroic fact; you just need small elements like this one.

P: "I came to therapy even when I didn't want to"?

T: Exactly. This means that you really had to mobilize enough decision, energy and willpower, isn't that right? I'm going to leave this third item for you to do as the day goes on. Now, tell me something: seeing these two elements here and remembering the 
viewpoint of the defense attorney (because this is a document of the defense, and, at this time, you are representing the defense, or allying yourself to her), how much do you believe this ("I am strong")?

P: I believe it $50 \%$.

T: Why don't you write here " $50 \%$ "? You can even modify this today, if you find another element. I'd like to ask you to, each day, put the date here in this space, seek out 3 elements, and daily, evaluate how much you believe this ("I am strong").

P: All right.

T: Maria, how much do you believe the negative core belief "I'm weak" now?

P: The same: $30 \%$.

$\mathrm{T}$ : And how strong is your sadness now?

P: Also the same: $20 \%$.

T: Ok? So, what will happen, or what do you hope will happen when you arrive with this information (that you gathered to work with your defense attorney) to answer the prosecutor's request for an appeal?

P: I'll be prepared for whatever comes from the prosecutor...

T: Exactly, that is the our goal, isn't it? And maybe another goal is to work in order for your defense attorney to gain more practice.

P: That as well.

T: She has been very silent or even absent for all these months, or years... Maria, if we could go back there... and if you could now tell me what the work we did here today meant to you, what would you tell me?

P: First of all, Dr. Oliveira, I'm going to leave here today feeling a bit stronger. Not as a strong person, but a little stronger than when I arrived here. I can see now the way my defense attorney was lying dormant all this time and I think that today I began to wake her up. Maybe, starting today, and especially with practice...

T: Ok. I only want to show you this diagram again [Therapist shows phase 1 of the TBCT conceptualization diagram to the patient in Fig. 1]; what do you see happened here (now, with this work we did)?

P: That I began to activate a little more this belief that was very weak or even inactive.

T: Exactly, it's as if it were here in this space, while the other belief was quite strong (you see this arrow going up and demonstrating that, since you are weak, normally the thoughts correspond to this). What if we looked at this other diagram, would you say that what happened here was exactly that? That is, what happened to this arrow? [Therapist shows phase 2 of the TBCT conceptualization diagram to the patient in Fig. 2]

P: It doesn't activate my negative core belief (that I am weak), it directly activates the belief that I am strong... 
T: Do you think it would be acceptable for us to write exactly this here: "I am strong"?

P: Yes, it would.

T: What do you imagine will happen now, while you have this positive belief "I am strong," in relation to this level that I explained to you in the beginning?

P: It is still a belief that doesn't stay activated the whole time, isn't it?

T: Ok, and would you say that it is activated now?

P: It is activated now.

T: And, being activated right now, what thoughts would you say are going on, in this space of ATs? [Therapist points to ATs box in the TBCT conceptualization diagram in Fig. 2]

P: ...that maybe I'll be able to deal with conversing with my husband.

TBCT Conceptualization Diagram after treatment.

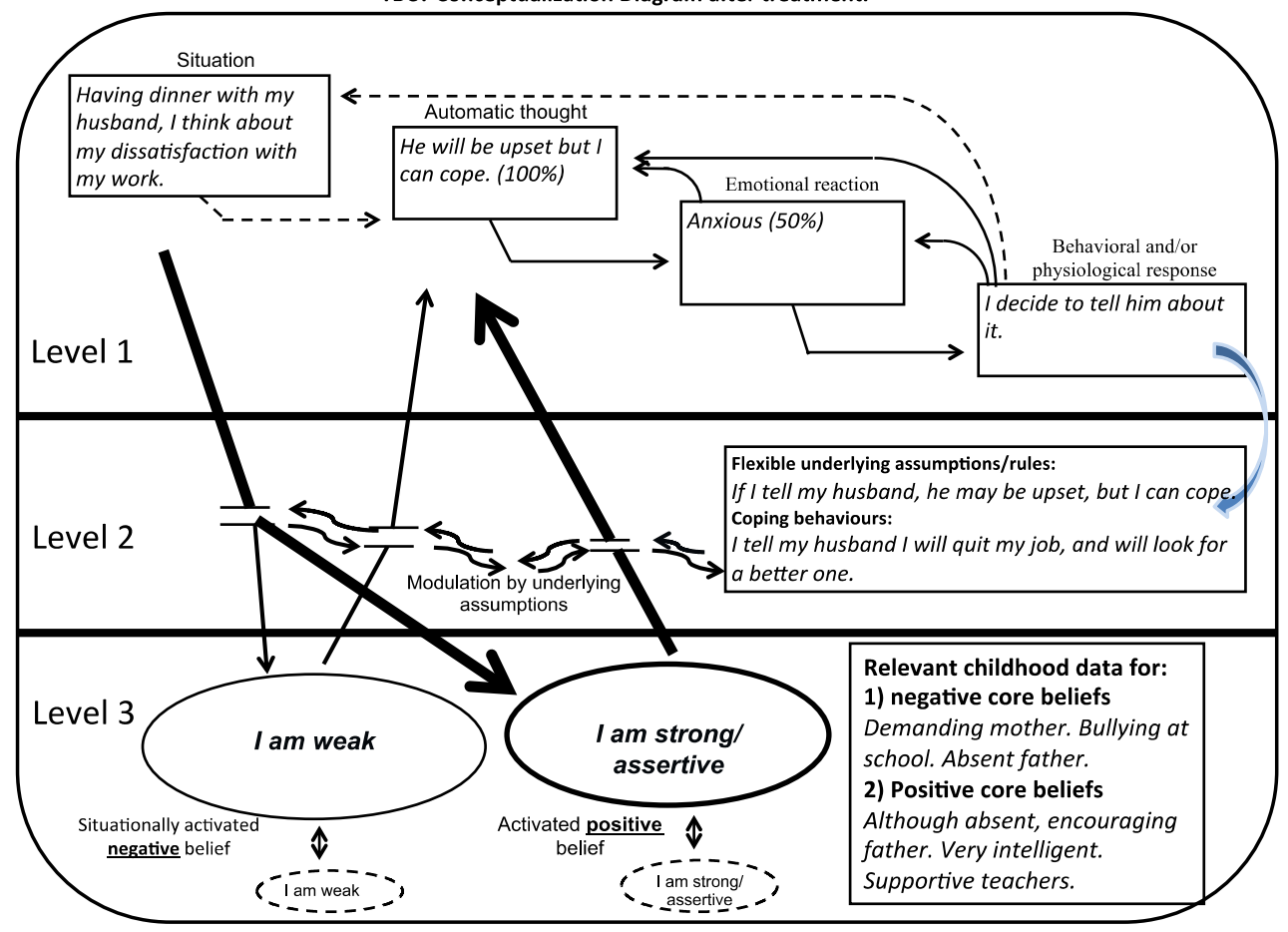

Fig. 2. Maria TBCT conceptualization diagram (Phase 2), showing the positive core belief activated more frequently after restructuring of cognitions with TBCT. 


\subsection{Obstacles to be avoided by the therapist when conducting a trial session}

Here are some of the obstacles therapists should avoid in order to make the TBTR work optimally:

1. Make sure that sentences are relatively short so that the patient has no problem when reversing them (long sentences are difficult to understand by the patient after sentence reversal);

2. Make sure that the defense attorney's arguments are not exclusively limited to responding to the prosecutor's plea; stimulate the patient to explore different aspects and areas of his/her life (other than the accusation);

3. If you do not succeed in finishing the Trial during one session, do not stop the Trial just after the prosecutor's plea; try always to stop it after the defense attorney's plea;

4. If the patient considers him/herself guilty, this is not a problem; the defense attorney should ask for an appeal so that the Trial can be repeated in the following session as an appeal; in this case, it is essential that homework be that the patient gather evidence that confirms the positive core belief (choosing the defense attorney as an ally);

5. If the patient decides (and this is rare) that s/he will continue working with the prosecutor instead of the defense attorney for homework assignment, interrupt the Trial and ask him/her for advantages and disadvantages of such a decision;

6. When the prosecutor interrupts the defense attorney's plea with "yes, but..." thoughts, gently tell the patient that the prosecutor should wait for his/her turn; on the other hand, if the patient tends to use the defense arguments when playing the role of the prosecutor, tell him that the defense attorney should wait for his/her turn (in this case, the patient should be praised for thinking positively, but, in any case, the patient should return to the prosecutor's plea);

7. Sometimes the negative core belief is so activated that, after reversion of the sentences, the patient does not succeed in seeing or admitting the positive side shown during the second defense attorney's performance (when searching for the meaning in the reversed sentence). In this case, ask him/her: Who is speaking now? If the patient recognizes the prosecutor acting, gently ask him/her the meaning of the sentence in the defense attorney's perspective, reminding him/her that this is the defense attorney's turn;

8. Sometimes, the patient has no evidence or argument as a prosecutor against the defense attorney's plea after the therapist reads the sentence and says "but..." In this case, draw a line and, when inverting the sentences, just copy the sentence and ask the patient what it means...;

9. The meaning of the reversed sentence should never be a broad interpretation; please, encourage the patient just to say what the sentence means by itself; that is fine when the patient brings meanings like: "I am intelligent," "I am normal," "I am a good father," etc.;

10. Finally, in some severe axis I disorders and in some personality disorder patients, even when the defense attorney is repeatedly successful in acquitting the patient, selfaccusation returns (negative core belief easily activated); in this case, use the Trial II (where the patient sues the prosecutor, accusing him/her of incompetence (never won a lawsuit), abuse (pursues the patient everywhere) and moral harassment 
(humiliates the patient). Results are amazing and durable. This is a step when the patient is informed and trained in taking some perspective (metacognition). The prosecutor has much less or no more credibility for him/her at this stage. It is advisable that the therapist be duly trained and supervised to engage in this step (deOliveira, 2011c).

\section{Conclusion}

Dealing with negative CBs will mobilize what is most significant for the patient, and consequently carry a strong emotional charge. This procedure should be carried out with extreme care and respect. It is suggested to non-experienced therapists that they utilize the Trial, if possible, at least initially, after training and supervision. ${ }^{* *}$

\section{Acknowledgements}

I am deeply indebted to Alessandra Mendonça Gomes and Tiana Coêlho da Gama Santos for important suggestions during the development of Trial-Based Cognitive Therapy. Their insights and comments made this approach much better than would have been possible without their help. Thanks are also due to Vania Powell - who helped me implement the studies - and to Donna Sudak and Amy Wenzel for intellectual assistance and guidance in the development of my work as a cognitive therapist.

\section{References}

Beck AT (1979) Cognitive therapy and the emotional disorders. New York: Meridian.

Beck AT, Epstein N, Brown G, Steer RA (1988) An inventory for measuring clinical anxiety: psychometric properties. Journal of Consulting and Clinical Psychology, 56:893897.

Beck JS (1995) Cognitive therapy: basics and beyond. New York: Guilford Press.

Burns DD (1980) Feeling Good: The New Mood Therapy. New York: Signet.

Carstenson B (1955) The auxiliary chair technique - a case study. Group Psychotherapy, 8:50-56.

De-Oliveira IR (2007) Sentence-reversion-based thought record (SRBTR): a new strategy to deal with "yes, but..." dysfunctional thoughts in cognitive therapy. European Review of Applied Psychology, 57:17-22.

De-Oliveira IR (2008) Trial-Based Thought Record (TBTR): Preliminary data on a strategy to deal with core beliefs by combining sentence reversion and the use of an analogy to a trial. Revista Brasileira de Psiquiatria, 30:12-18. (free pdf version available at http://www.scielo.br/pdf/rbp/v30n1/a03v30n1.pdf).

De-Oliveira IR (2011a) Downward/upward arrow: Accepted entry in Common Language for Psychotherapy Procedures (www.commonlanguagepsychotherapy.org, retrieved in August 7, 2011).

De-Oliveira IR (2011b) Kafka's trial dilemma: Proposal of a practical solution to Joseph K.'s unknown accusation. Medical Hypotheses, 77:5-6.

\footnotetext{
${ }^{* *}$ Information on training and supervision may be found in http://trial-basedcognitivetherapy.com/.
} 
De-Oliveira IR (2011c) Trial-based cognitive therapy: Accepted entry in Common Language for Psychotherapy Procedures (www.commonlanguagepsychotherapy.org, retrieved in August 7, 2011).

De-Oliveira IR (2011d) Trial-based thought record: Accepted entry in Common Language for Psychotherapy Procedures (www.commonlanguagepsychotherapy.org, retrieved in August 7, 2011).

De-Oliveira (2011e) Uso do "Processo" para modificar crenças nucleares disfuncionais. In: Rangé B, Diálogo com a Psiquiatria. Artmed, Porto Alegre.

De-Oliveira IR, Pereira MO (2004) Questionando crenças irracionais. In: Abreu CN \& Guilhardi HJ. Terapia comportamental e cognitivo-comportamental: práticas clínicas. São Paulo, Roca. 482 p.

De-Oliveira IR, Powell VB, Wenzel A, Seixas C, de-Almeida C, Grangeon MC, Caldas M, Bonfim T, Castro MM, de-Almeida AG, Moraes RO, Sudak D (2011) Controlled study of the efficacy of the Trial-Based Thought Record (TBTR), a new cognitive therapy strategy to change core beliefs, in social phobia. Journal of Clinical Pharmacy and Therapeutics, in press (doi:10.1111/j.1365-2710.2011.01299.x).

Freeman A, DeWolf R (1992) The 10 dumbest mistakes smart people make and how to avoid them. New York: HarperPerennial.

Greenberger D, Padesky CA (1995) Mind over mood. New York: Guilford Press.

Kafka F (1998) The trial. New York: Schocken (first published in 1925).

Leahy RL (2003) Cognitive therapy techniques. A practitioner's guide. New York: Guilford Press.

Leahy RL, Tirch D, Napolitano LA (2011) Emotion regulation in psychotherapy. New York: Guilford Press.

Liebowitz MR (1987) Social phobia. Modern problems in pharmacopsychiatry, 22:141173.

Watson D, Friend R (1969) Measurement of social-evaluative anxiety. Journal of Consulting and Clinical Psychology, 33:448-457.

Wenzel A (2012) Modification of core beliefs in cognitive therapy. In: De-Oliveira (ed.) Cognitive-behavioral therapy. InTech, Rijeka, Croatia. 


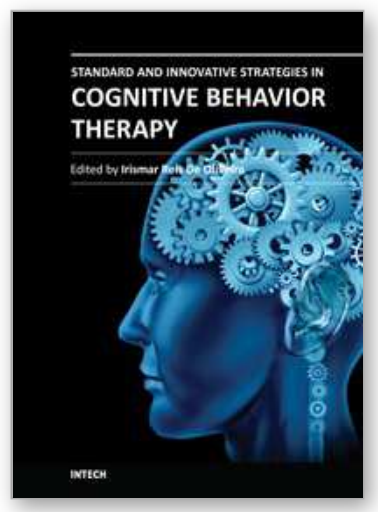

\author{
Standard and Innovative Strategies in Cognitive Behavior Therapy \\ Edited by Dr. Irismar Reis De Oliveira
}

ISBN 978-953-51-0312-7

Hard cover, 190 pages

Publisher InTech

Published online 14, March, 2012

Published in print edition March, 2012

Cognitive-behavioral therapy (CBT) is the fastest growing and the best empirically validated psychotherapeutic approach. Written by international experts, this book intends to bring CBT to as many mental health professionals as possible. Section 1 introduces basic and conceptual aspects. The reader is informed on how to assess and restructure cognitions, focusing on automatic thoughts and underlying assumptions as well as the main techniques developed to modify core beliefs. Section 2 of this book covers the cognitive therapy of some important psychiatric disorders, providing reviews of the recent developments of CBT for depression, bipolar disorder and obsessive-compulsive disorder. It also provides the latest advances in the CBT for somatoform disorders as well as a new learning model of body dysmorphic disorder. Two chapters on addiction close this book, providing a thorough review of the recent phenomenon of Internet addiction and its treatment, concluding with the CBT for substance abuse.

\title{
How to reference
}

In order to correctly reference this scholarly work, feel free to copy and paste the following:

Irismar Reis de Oliveira (2012). Use of the Trial-Based Thought Record to Change Negative Core Beliefs, Standard and Innovative Strategies in Cognitive Behavior Therapy, Dr. Irismar Reis De Oliveira (Ed.), ISBN: 978-953-51-0312-7, InTech, Available from: http://www.intechopen.com/books/standard-and-innovativestrategies-in-cognitive-behavior-therapy/use-of-the-trial-based-thought-record-to-change-dysfunctional-corebeliefs

\section{INTECH}

open science | open minds

\section{InTech Europe}

University Campus STeP Ri

Slavka Krautzeka 83/A

51000 Rijeka, Croatia

Phone: +385 (51) 770447

Fax: +385 (51) 686166

www.intechopen.com

\section{InTech China}

Unit 405, Office Block, Hotel Equatorial Shanghai

No.65, Yan An Road (West), Shanghai, 200040, China

中国上海市延安西路65号上海国际贵都大饭店办公楼 405 单元

Phone: +86-21-62489820

Fax: $+86-21-62489821$ 
(C) 2012 The Author(s). Licensee IntechOpen. This is an open access article distributed under the terms of the Creative Commons Attribution 3.0 License, which permits unrestricted use, distribution, and reproduction in any medium, provided the original work is properly cited. 